\title{
Epidural block and neostigmine cause anastomosis leak
}

This article was published in the following Dove Press journal:

Open Access Surgery

20 May 2016

Number of times this article has been viewed

\section{Getu Ataro \\ Department of Anesthesia, Jimma University, Jimma, Ethiopia}

Correspondence: Getu Ataro Department of Anesthesia, Jimma University, PO Box 378, Jimma, Ethiopia Email getsha@yahoo.com

\section{Dear editor}

I read the article by Phillips entitled, "Reducing gastrointestinal anastomotic leak rates: review of challenges and solutions", published in the journal of Open Access Surgery with enthusiasm and found it crucial for perioperative management of patients with gastrointestinal (GI) surgery, particularly anastomosis. I appreciate the author's exhaustive search of literature and discussion with some limitation on review basics like methodology, which may affect the reliability of the review findings. The effects of risk factors for anastomosis leak, such as malnutrition, smoking, steroid use, bowel preparation, chemotherapy, duration of surgery, use of pressors, intravenous fluid administration, blood transfusion, and surgical anastomotic technique, were well discussed. ${ }^{1}$ However, from anesthesia perspective, there are some other well-studied risk factors that can affect healing of anastomosis wound and cause anastomosis leak. Among others, the effect of neostigmine and epidural block has been reported in many studies since half a century ago.

\section{Summaries}

\section{Neostigmine}

Neostigmine has commonly been used for reversal of nondepolarizing neuromuscular blockade during general anesthesia. Being an anticholinesterase, neostigmine increases GI motility through the muscarinic effect of acetylcholine. ${ }^{2}$ Although atropine is known to oppose the muscarinic effect of neostigmine, anastomosis leak was reported in patients who were injected both neostigmine alone and neostigmine combined with atropine for GI surgery. ${ }^{3}$ This adverse effect of neostigmine can be minimized by using halothane anesthesia. ${ }^{4}$ Moreover, administration of neostigmine increased the rate of anastomosis leak from $4 \%$ to $36 \%{ }^{5}$

\section{Epidural}

Epidural block is used for the perioperative pain management of surgical patients. When it is used for GI surgeries, epidural block has several clinical benefits similar to high spinal blocks. ${ }^{6-8}$ However, thoracic epidural block with local anesthetics increases the GI motility, mainly through blocking sympathetic fibers and causing unopposed dominance of the parasympathetic effects. ${ }^{9}$ For the perioperative use of vasopressors reported as a risk factor for anastomosis leak, ${ }^{1}$ epidural block-induced hypotension 
and shock are some of the main reasons. Results of a review showed that epidural block increased anastomosis risk from $3.4 \%$ to $6.0 \% .^{10}$

The risk of anastomotic leak can be reduced if all perioperative factors are controlled. Among the perioperative factors, anesthesia-related one should not be overlooked. Use of neostigmine can be minimized by using a depolarizing muscle relaxant that normally does not need reversal with neostigmine. Maintenance of analgesia with epidural opioids also avoids excessive use of local anesthetics that persistently block sympathetic fibers. Finally, challenges and solutions of anastomosis leak should consider the aforementioned factors in reviews to come up with best results and recommendations.

\section{Disclosure}

The author reports no conflicts of interest in this communication.

\section{References}

1. Phillips BR. Reducing gastrointestinal anastomotic leak rates: review of challenges and solutions. Open Access Surgery. 2016;9:5-14.

2. Nair VP, Hunter JM. Anticholinesterases and anticholinergic drugs. Continuing education in anaesthesia. Crit Care Pain. 2004;4(5):164-168.

3. Wilkins JL, Hardcastle JD, Mann CV, Kaufman L. Effects of neostigmine and atropine on motor activity of ileum, colon, and rectum of anaesthetized subjects. Br Med J. 1970;1(5699):793-794.

4. Keighley MRB, Williams NS. Surgery of the Anus, Rectum and Colon. London: WB Saunders; 1993.

5. Bell CM, Lewis CB. Effect of neostigmine on integrity of ileorectal anastomoses. Br Med J. 1968;3(5618):587-588.

6. Aitkenhead AR, Wishart HY, Brown DA. High spinal nerve block for large bowel anastomosis: a retrospective study. $\mathrm{Br} J$ Anaesth. 1978;50:177-182.

7. Worsley MH, Wishhart HY, Peebles Brown DA, Aitkenhead AR. High spinal nerve block for large bowel anastomosis: a prospective study. Br J Anaesth. 1988;60:836-840.

8. Freise H, Van Aken HK. Risks and benefits of thoracic epidural anaesthesia. Br J Anaesth. 2011;107(6):859-868.

9. Ulke ZS, Senturk M. Non-analgesic effects of thoracic epidural anesthesia. Agri. 2007;19:6-12.

10. Holte K, Kehlet H. Epidural analgesia and risk of anastomotic leakage. Reg Anesth Pain Med. 2001;26(2):111-117.

Dove Medical Press encourages responsible, free and frank academic debate. The content of the Open Access Surgery 'letters to the editor' section does not necessarily represent the views of Dove Medical Press, its officers, agents, employees, related entities or the Open Access Surgery editors. While all reasonable steps have been taken to confirm the content of each letter, Dove Medical Press accepts no liability in respect of the content of any letter, nor is it responsible for the content and accuracy of any letter to the editor.

\section{Dovepress}

\section{Publish your work in this journal}

Open Access Surgery is an international, peer-reviewed, open access journal that focuses on all aspects of surgical procedures and interventions. Patient care around the peri-operative period and patient outcomes post surgery are key topics. All grades of surgery from minor cosmetic interventions to major surgical procedures are covered. Novel techniques and the utilization of new instruments and materials, including implants and prostheses that optimize outcomes constitute major areas of interest. The manuscript management system is completely online and includes a very quick and fair peer-review system. Visit http://www.dovepress.com/ testimonials.php to read real quotes from published authors. 